\title{
The Brazilian Editor's Note
}

I am pleased to introduce our readers to the special issue on Language Policy and Planning of the RevistaBrasileira de LinguísticaAplicada (RBLA).

The issue brings a global and multilingual outlook on issues ranging from language revitalization and maintenance to attitudes and motivation. The papers approach both educational contexts and language use out of school settings. From the point of view of the Brazilian readership of RBLA, we hope that this issue will come as source of ideas and thoughts to inspire questions. This special issue comes to our readers when Brazil may be said to be at a unique time in its history with regard to potential policy-making and calls for intervention in language issues, especially languages other than Portuguese. For instance, it is well known that major government investments are being made for the internationalization of university-level training through programs such as CAPES" "Science without Frontiers", a context thathas led the administration of some universities to install task forces to face the challenges of increased demands for language instruction, as well as the assessment of ability in foreign languages. Another sign of a changing scenario is the fact that Brazilians are now just two years away from the first inclusion of foreign languages in the Brazilian national program of free textbook distribution for public schools, an event that can certainly be understood as a major language-in-education policy. We believe that Brazilian Applied Linguistics is immersed in a context which encourages advancement of language policy and planning as an area of study. It is as a response to our perception of such context that we present the papers in this issue.

We open the special issue with an introduction by our guest editor, Prof. Richard Baldauf, from the University of Queensland, Australia. Prof. Baldauf is a leading expert in the field of language and language-in-education policy and planning. In his introduction Prof. Baldauf reports the birth and development of language policy and planning as an academic discipline, and he also proposes six key issues that may set the directions where the discipline is heading to. Prof. Baldauf's paper not only informs readers new to studies of language policy and planning of the foundations of the field, but it also places the articles in this collection - which I briefly introduce below - within a broader disciplinary context. We express our sincere thanks to Prof. Baldauf for his invaluable contribution to this issue. 
The two first articles in this issuedeal with the perspective of English as a lingua franca. Schmitz offers readers with a review of scholarship on such perspective, exploring the implications of a proposed shift from the nativespeaker as the single source of norms to guide English language teaching and testing, and inviting readers to consider the challenges and opportunities it brings to the practice of applied linguistics and language pedagogy. VodopijaKrstanoviæ \& Brala-Vukanoviæ contribute to our understanding of such challenges and opportunities with empirical data from a study in Croatian tertiary education, where the authors find adherence to native-speaker norms to be prevalent. The authors highlight the urgency of both descriptive studies of international Englishes and of policies that foster their presence in educational settings if it is desired that recognition of the lingua franca status of English is ever to become a robust guideline for teaching and learning.

The next two articles exemplify how facets and corollaries of educational policies, as well as responses towards them, may intervene either directly or indirectly with questions of language ability, thusimpacting favorably or unfavorably on the availability of language skills as a human resource for societies.Burke \& Oliveira report the historical context of the "No Child Left Behind" Act in the USA, and the ensuing growth of educational standardized tests in that country. The authors review studies that analyze the impact of the "No Child Left Behind" Act as a measurement that may unofficially turn English into an official American language, putting the existence of languages other than English in the United States at jeopardy. Almeida discusses the recent history of English as a foreign language education in the Brazilian public education system and proposes an interpretation of official documents aimed at setting goals for the discipline. The author revisits a Brazilian debate about whether or not oral language skills should be a goal in public language education, and voices a criticism of the current guidelines for public school foreign textbook quality evaluation.

The three lastarticles in this special issue move between the resonances of globalization in societal language practices and issues to localization, by discussing and detailing initiatives of language maintenance and revitalization. Singh, Zhang \&Besmeloffer an analysis of the impact of globalization and the present world economic landscape on language practices and policies in multilingual societies, discussing how Afghanistan, China, India and Nepal manage the challenging equation of maintaining multilingualism in face of the pressures of global languages. Ting's article contains a study of the 
implementation of national language policy programs with three ethnic groups of the Malaysian state of Sarawak. The report shows a sociolinguistic profile of those populations and reveals differences in the impact that national language policy programs had on them. The author interprets such findings in articulation with a game theory of language policy outcomes. Picanço reports efforts for the description and codification of a minority Tupian language spoken in northern Brazil. The author reports a revitalization project conducted in the Kwatá-Laranjal indigenous land in the state of Pará. Such program coordinated efforts to conduct sociolinguistic profiles, to codify orthography for the language and to foster language educationin the indigenous community.

We hope that readers of this special issue deepen their insight of the changing world where localization and globalization stand in dialectal tension in concern with language issues. We also hope that the collection of articles as a whole inspire readers to examine perspectives for applied linguists and language educators in the promotion of fair access to language rights and resources at the societal level. 